\title{
Process Optimization and Influence of Micro Structural Characterization by Friction Stir Welding of Various Materials
}

\author{
Mahendra K C, Sreenivasa C. G., Veerabhadrappa Algur, Virupaksha Gouda H
}

\begin{abstract}
Various advanced joining techniques are available now days to suit the process challenges and to connect the specific application areas of industrial sector. Several experimental investigations on mechanical characteristics of different materials along with process parameters are successfully joined and evaluated. Friction stir welding (FSW) defines a solid state bonding operation, which uses a non-consumable tool to join the workpiece material. Friction stir welding technique can be applied to weld the similar and dissimilar materials including ferrous, nonferrous and polymers to develop sustainable byproduct. Industrial applications in the fields of automobiles, aerospace are expecting the techniques to join various combinations of materials for lightweight and improved performance from engineering designs that ensures the fulfillment of current challenging desires. As the research intensifies into wider aspects like obtaining suitable material combinations to attain the objective of reduced weight and also to satisfy applications aspects, friction stir welding gave perfect platform to exhibit newer material integration. Objective of this paper is to research and analyze the influence of critical parameters through FSW. In this direction, review based on process based methodology of different materials combinations like ferrous materials, non-ferrous materials and dissimilar material has been focused. Welding parameters influencing the FSW operations and their effect on mechanical properties in the respective categories of material pooling has been indicated. Tensile test, hardness inspection, macro and microstructural evaluations of subjected materials have been highlighted in this section. This suggest with further recommendations that FSW can also be applied effectively in case of polymeric materials in continuance of research domain.
\end{abstract}

Keywords: Dissimilar Materials, Friction Stir Welding, Microstructure, Tensile Strength,

Revised Manuscript Received on December 30, 2019.

* Correspondence Author

Mahendra K C, Asst Prof, Department of Mechanical Engineering, Rao Bahadur Y. Mahabaleshwarappa Engg College Ballari, Karnataka, India. E-mail: Mahiubdt@gmail.com

Sreenivasa C. G. Associate Professor, Department of Mechanical Engineering, UBDTCE, Davangere. Karnataka, India.

E-mail: sreenivasacg@gmail.com

Veerabhadrappa Algur, Associate Professor, Department of Mechanical Engineering, Rao Bahadur Y. Mahabaleshwarappa Engg College Ballari, Karnataka, India. Email: veereshalgur@gmail.com

Virupaksha Gouda H, Asst Prof ,Department of Mechanical Engineering Rao Bahadur Y.Mahabaleshwarappa Engg College Ballari, Karnataka, India. E-mail: Virupaksha.rymec@gmail.com

(C) The Authors. Published by Blue Eyes Intelligence Engineering and Sciences Publication (BEIESP). This is an open access article under the CC BY-NC-ND license (http://creativecommons.org/licenses/by-nc-nd/4.0/)

\section{INTRODUCTION}

Early days of civilization and the inception of small-medium scale industries, materials especially materials find their implementation in various sectors to meet the growing industrial demands. Engineering materials are extensively used for all the mechanical embedded process like manufacturing, fabrication and other joining operations. Based on their structures and behavioral properties suitable selection can be made to carry out the experimental oriented process. Research on various compound materials location and its origin are going in a rapid phase to extract unique properties that suits for specific application sectors. Most of the available commercial materials like steel continue to cover a wide range of structural approach, but currently many process operations intent towards developing of light weight components for successful and economical usage. Light weight structural components of automobiles are beneficial to fuel economy, driving performance ability and greenhouse emissions to environment. Rising fuel prices as well as tightened automotive regulations engulfs the automobile manufacture ring unit to develop low fuel consumption engines and lightweight parts. Technical strategy for vehicle element in weight reduction is to restore conventional materials such as steels with lighter ones such as light metals and polymers. Nevertheless industries still have insufficient knowledge on the developing of reliable and economical structures. This is particularly in the case of hybrid structures where metals to thermoplastics significant differences in material properties exist. Hence for this reason, steels have been replaced by newer combination of materials to enhance the process parameters and to obtain better mechanical properties. Utilization of plastic materials in engineering structures has increased because of benefits occurring from their low weight, high specific strength and elastic modulus, design flexibility, and reduced manufacturing costs [1]. Traditional welding process like joining metal to metal, metal to dissimilar and various weldments are the commonly practiced tasks. Conventional welding offers some credential aspects like feasible performance and strong bonding. However they also resulted in some serious drawbacks like harmful radiations, fumes, gases and distortion of work piece. These factors contributed the researchers to focus on developing newer merging technique called Friction Stir Welding (FSW). This performance inclination can be applied to diversified materials including ferrous and non ferrous materials depending upon the experimental and application field requirements.

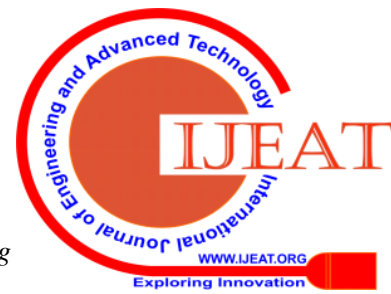


In this connection the objective of this paper deals with recent findings of joining similar and dissimilar blending of materials based on friction Stir Welding and identify the gap for newer investigations.

FRICTION STIR WELDING: Friction stir welding is a process in which, metallic parts are joined without attaining the melting point. It was invented by Wayne Thomas at TWI, and the first patent applications were applied in the UK in December 1991. Heating action is carriedout by friction effort between the tool and workpiece. Plastic deformation of workpieces maintains a union past the tool formation of workpieces leads to a union past the tool. Localized heating influence softens material around the pin and assembly of tool rotation and translation guides moving of material from the forward of the pin to the back of the pin. In consequence, a joint will be formed in solid state [2].

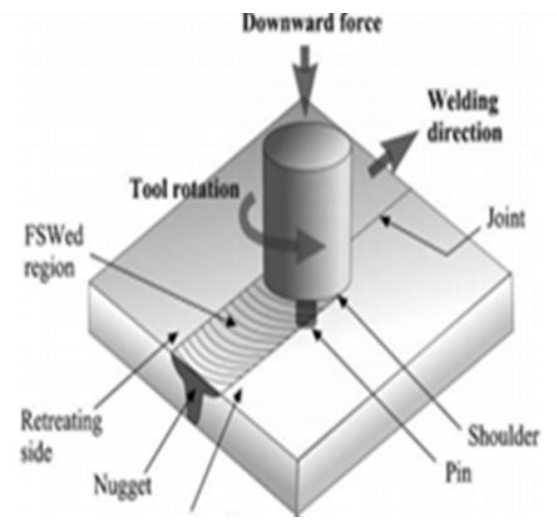

Fig 1: Illustration of friction stir welding process [3].

\section{LITERATURE REVIEW}

Based on FSW process, research findings of various materials and their combinations, process parameters selected for experimental investigations were highlighted in the literature survey. The methodology section focuses on following aspects with respect to friction stir welding of:

A. Ferrous Materials.

B. Non-Ferrous Materials.

C. Dissimilar Material Combinations.

\section{A. Friction stir welding of ferrous materials.}

Saman Karami et al. investigated the microstructural and welding parameters of austenitic stainless steel by Friction Stir Welding. Macroscopic analysis indicated that samples detected with some flaky surfaces in the weldments. Increase in transverse speed resulted in decrease in heat input and increase in welding speeds caused decrease in associating time between pin and workpiece. Analysis of base metal with respect to microstructure view stated that the phase transformation of austenite to ferrite and pearlite structure along with austenite phase area in the heat affected zone. [4]. R. Ramesh et al. Study focused upon applying FSW technique to High strength low alloy steel (HSLA). Some defects occurred because of reduced heat input and improper stirring. Quantity of upper bainite is decreased by increase in welding speed. Microstructure of weld nugget confirmed the involvement of phase's ferrite and pearlite. However improvement on microstructure of base metal was drastically improved in the zone of weld nugget [5].

\section{B. Friction stir welding of non-ferrous materials.}

Pankaj kumar, Satpal Singh analyzed the parameters of friction stir welded copper joints. Study employed full factorial design matrix by taking variables like rotational speed, tool travel speed and also keeping tool material fixed throughout the experimentation. Tensile strength of welded specimens is within the range of 62 to $112 \mathrm{MPa}$. Higher rotational speed gives better tensile strength, as the average tensile strength with $5000 \mathrm{rpm}$ is $95 \mathrm{MPa}$. With increasing traverse speed the contact time decreases and less heat generated at that specific point and lower the tensile strength [6]. Dr. K. Lenin and Dharmalingam demonstrated the flexibility of joining the copper plates by friction stir welding. Tensile strengths of weld joint developed with 19 $\mathrm{mm} / \mathrm{min}$ of welding speed were found higher comparing to that of base material. [7]. Sreenivas P, Sreejith P S analyzed the parameters and microstructural evaluation of AA 2219 alloy. Welds generated by the threaded pin profile exhibited maximum tensile strength and microhardness. In case of AA2219 alloys, Al2Cu precipitates were identified as the second phase particles in the nugget zone. SEM and EDS analysis suggest that the precipitation of the $\mathrm{Al} 2 \mathrm{Cu}$ particles was more for the welds generated by the threaded pin profile [8].

\section{Friction stir welding of dissimilar material combinations.}

Buddi Manohar et al. Analysis carried out to investigate mechanical factors of dissimilar aluminum alloy AA5083 and AA6061 and examining the effect of microstructures. Mechanical properties relying on the parameters like rotational speed, tool speed and also axial force were considered. Grain arrangement within the nugget is fine and equiaxed, grain size is predominantly lesser than the initial materials because of advanced temperature and intense plastic deformations due to stirring activity by the tool probe [9]. S. Thirumavalavan et al. studied friction stir welding of aluminum -scilicon alloy (Al-Mg-Si alloy).Taper cylindrical threaded pin of refined $3-4 \mathrm{~mm}$ of size near to weld nugget. Fine refinement of grains around the weld nugget indicating that taper cylindrical threaded pin yielded preferable welds on comparison with the rest of the profiles. In case of tensile test, pins with threaded profile have superior tensile characteristics with respect to the unthreaded pins. Taper cylindrical threaded pin profile gave better elongation characteristics of $14.867 \%$. Micro-Vickers test justifies that welds made up of taper threaded pin of cylindrical profile has hardness value of 68.71 VHN [10]. Hassan Abd El-Hafez, Abla El-Megharbel aluminum alloys of series AA2024-T365 and AA5083-H111 were welded. Optical inspection of the specimens involving defects such as tunnel and voids at the region of welded zone. Tensile strength was notable at welding speed of $80 \mathrm{~mm} / \mathrm{min}$. Microstructures noticed that the stirring behavior as well as the blending of alloys varied from one specimen to another. In the stirring zone profile shape of square pin generates better strength because of pulsed nature that produced good metal flow, as a result of effective stirring [11]. Yudhvir et al. rotation speed, traverse speed and tool tilt angle were selected for analysis using cause and effect diagram Results showed that tests for .

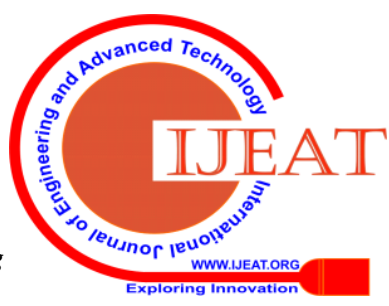


Tensile strength yielded from $0.141 \mathrm{kN} / \mathrm{mm} 2$ to $0.091 \mathrm{kN} / \mathrm{mm} 2$. Rockwell Hardness variation is from 62 HRC to 27 HRC. It was noticed that Tool rotational speed contributed significantly on comparison to all the parameters [12].

\section{METHODOLOGY}

The proposed methodology is given in the form of flowchart as shown in the Fig: 3.1.

Collecting the various research articles or literatures based on friction stir welding.

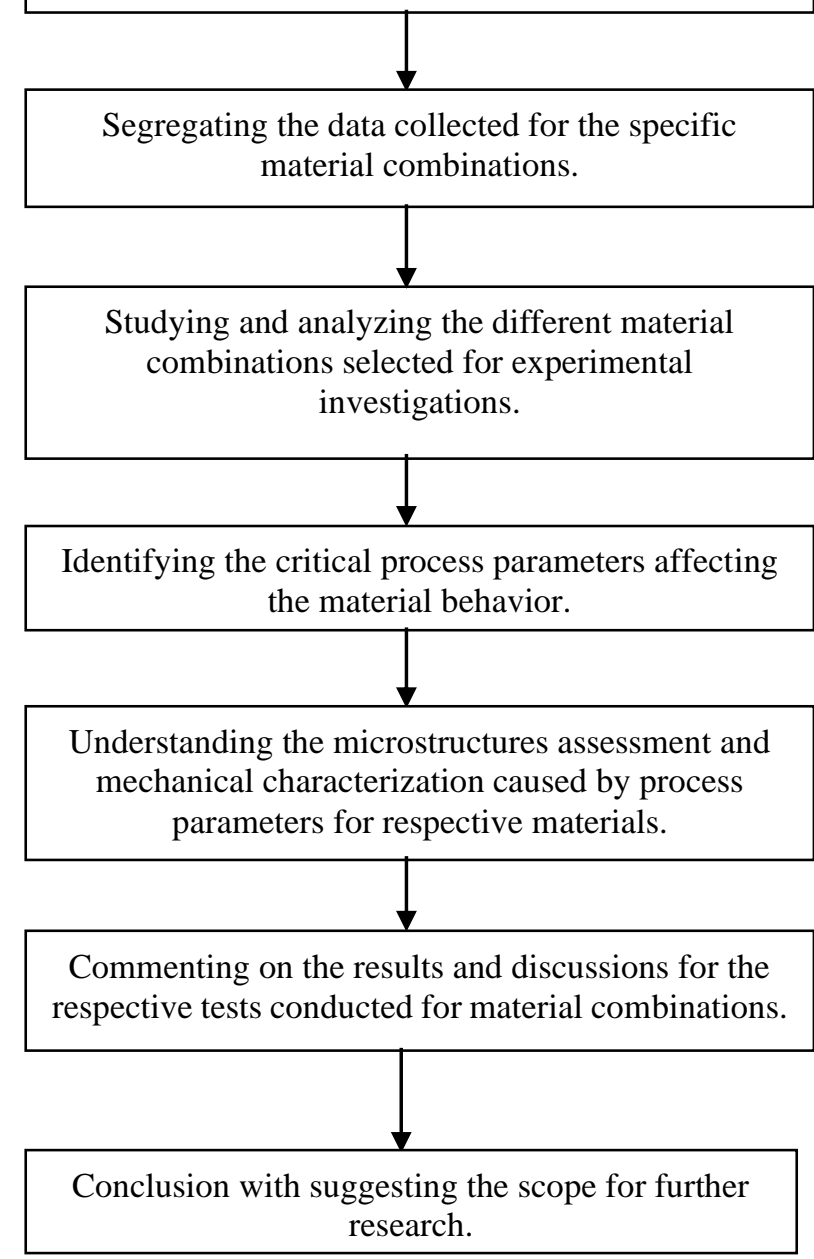

Fig 3.1: Flow chart

\section{MICROSTRUCTURES AND MECHANICAL CHARACTERISATION}

\subsection{Ferrous Materials}

\subsubsection{Mild steel}

Comparing the Fig 4.2 demonstrated that the fraction area of HAZ in sample 1 is larger than sample 2 indicating that increasing the rotation speed can cause an increase in heat input and these results in increase the fraction of HAZ area. Increasing the welding speed and decrease of rotation speed can significantly limit the HAZ area. Microstructure of base metal consisted of equiaxed ferrite phase with grain size along with pearlite as shown in Fig 4.1. In heat affected zone total grain refinement area is close to stir zone, temperature at this stage reach to single phase austenitic area as shown in Fig 4.3.On cooling relatively fine austenite grains transform

to finer ferrite and pearlite. Some flaky surfaces occurred in weldments from macroscopic analysis as shown in Fig 4.4.

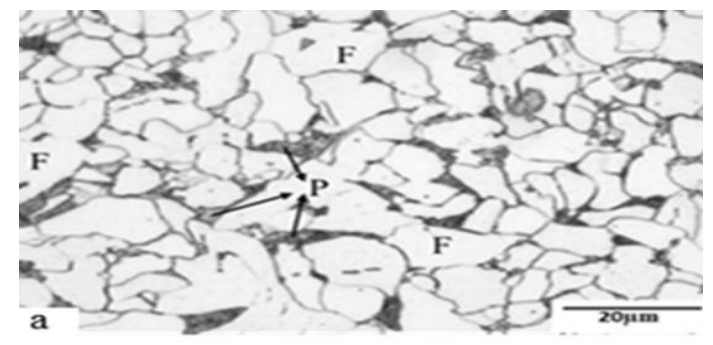

Fig 4.1: Micrograph of the base metal [4]

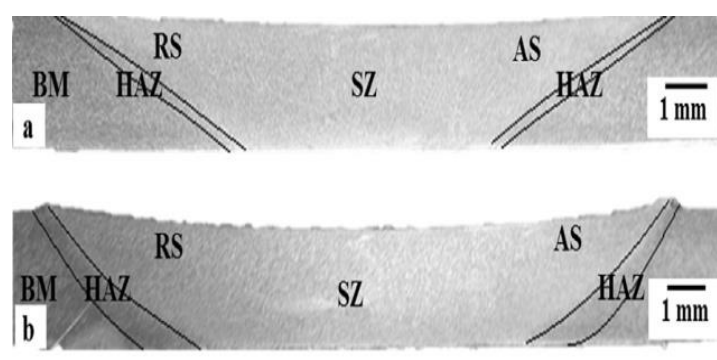

Fig 4.2: Micrograph of a transverse section of a friction stir weld on 1018 steel [4]

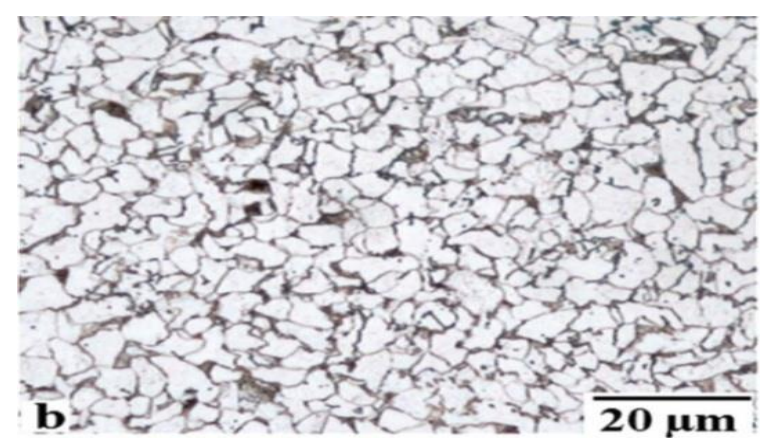

Fig 4.3: Optical micrographs of HAZ regions [4]
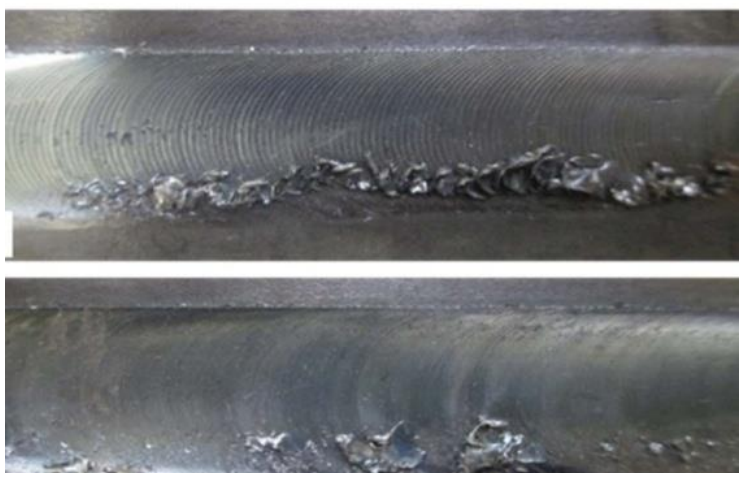

Fig 4.4: Image of the weld bead- flaky surfaces [4]

4.1.2 High strength low alloy steel

Tensile strength test suggested that a maximum joint efficiency with respect to traverse speeds as shown in Fig 4.5. The average grain size reduced with an increase in traverse speed as mentioned in the Fig 4.6. Microstructure of the base metal is significantly refined in the weld nugget.

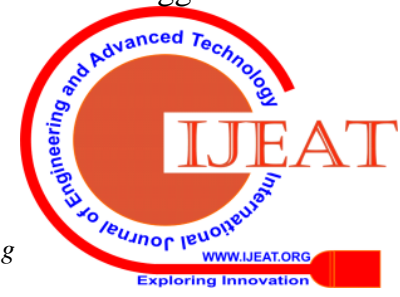


The microstructure of all the weld nuggets is not same which suggests that the welding conditions greatly influenced the resultant microstructure subsequent to welding. Weld nugget confirmed the presence of two major stages namely ferrite and pearlite as shown in Fig 4.7. It is evident from Fig 4.7 that, weld nugget microstructure is composed of upper bainite and fine ferrite.

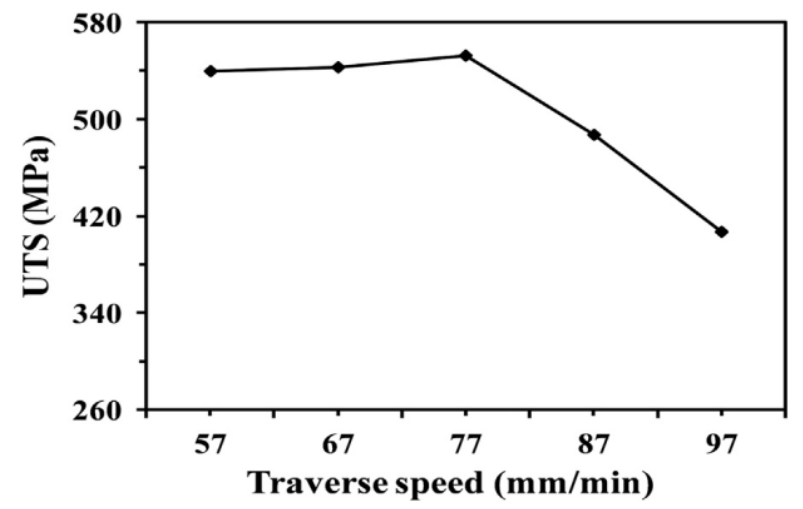

Fig 4.5: Effect of traverse speed on tensile strength [5]

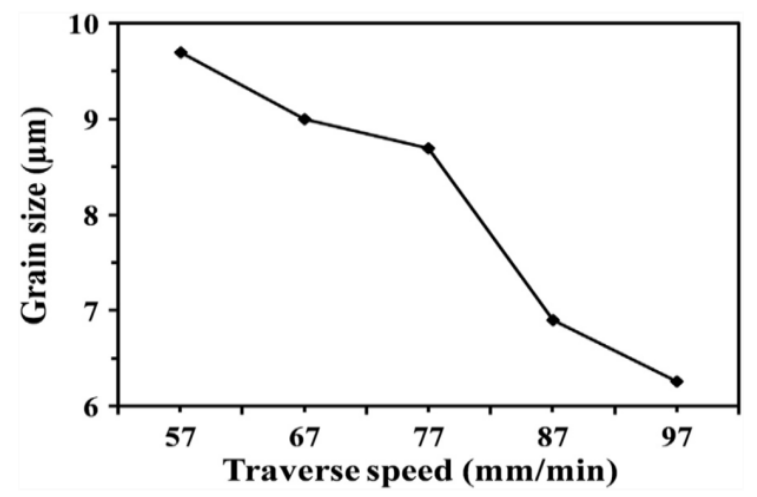

Fig 4.6: Effect of traverse speed on grain size [5]
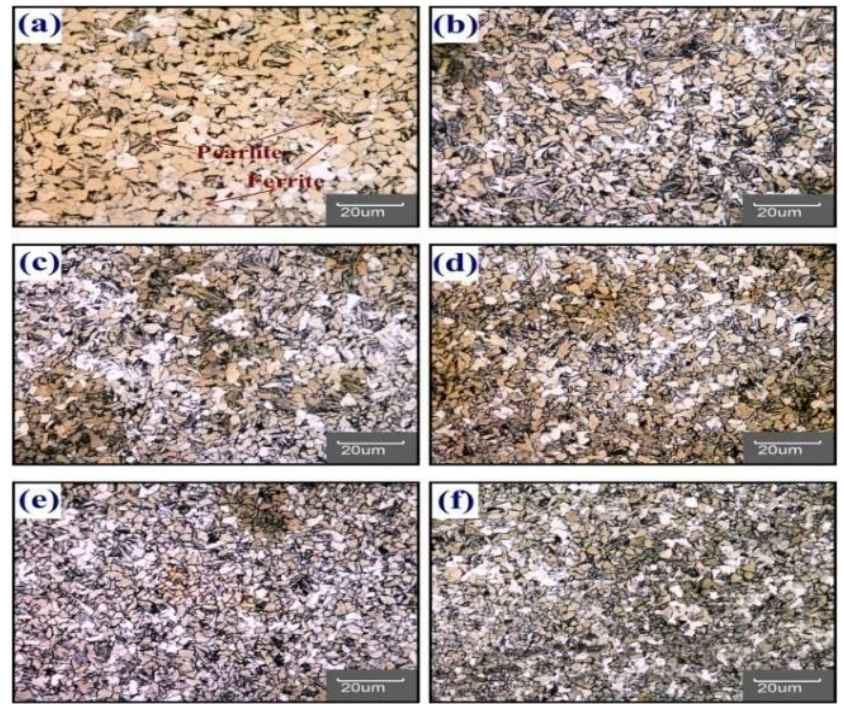

Fig 4.7: Optical macrograph at various traverse speeds [5]

\subsection{Non Ferrous Materials}

\subsubsection{Copper}

Rotational speed of tool shows its influence on tensile; higher rpm gives better tensile strength as shown in Fig 4.8. Increasing traverse speed, contact time decreases leading to reduced heat generation at that specific point and lower the tensile strength.

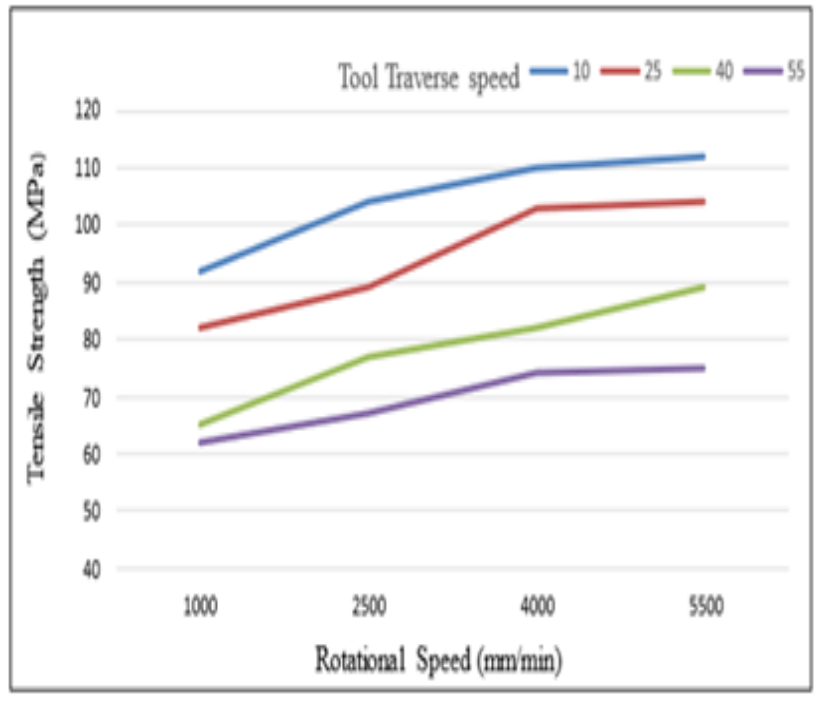

Fig 4.8: Tensile behavior of FSW joints for varying rotational speed with different travel speed [6]

4.2.2 Copper

Microstructure of the weld nugget is very fine, with a grain size of about 11 microns as shown in Fig 4.9. TMAZ zone is signalized by small-grain structure at the same time it is exposed to plastic deformation and the effect of temperature. Structure of the weld in the HAZ zone is almost identical to that of the base material, indicating a productive weld as shown in Fig 4.9. It should be noted that grain size is the largest in the HAZ of retreating side (RS) part. Hardness of weld nugget produced using lower welding speed was found be more than that produced using higher welding speeds as shown in Fig 4.10. Defect free welds were obtained as shown in Fig 4.11.

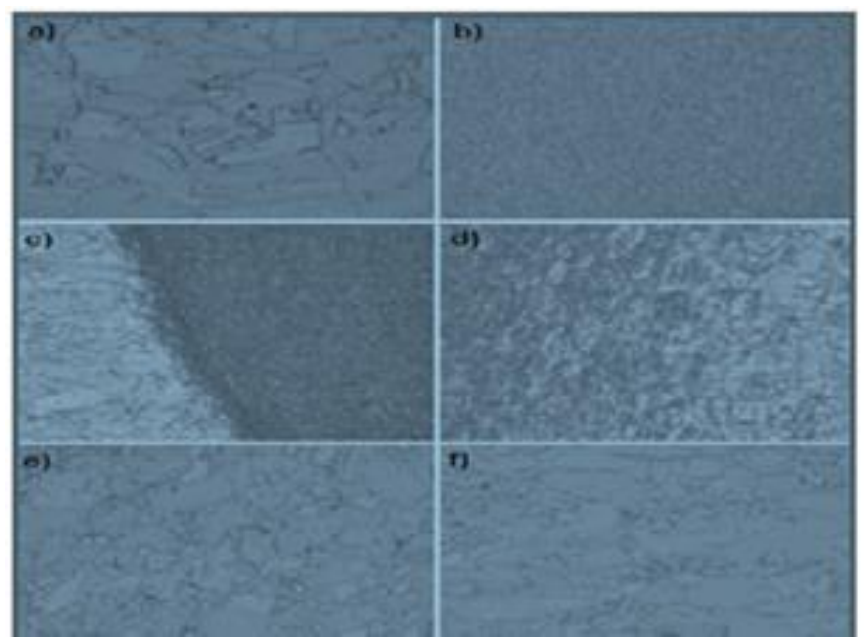

Fig 4.9: Microstructure of a) base metal, b) nugget zone, c) TMAZ of TMAZ, d) TMAZ of RS, e) HAZ of AS of f) HAZ of RS [7]

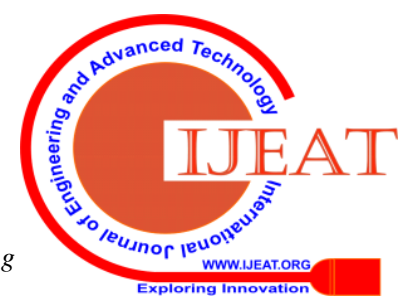




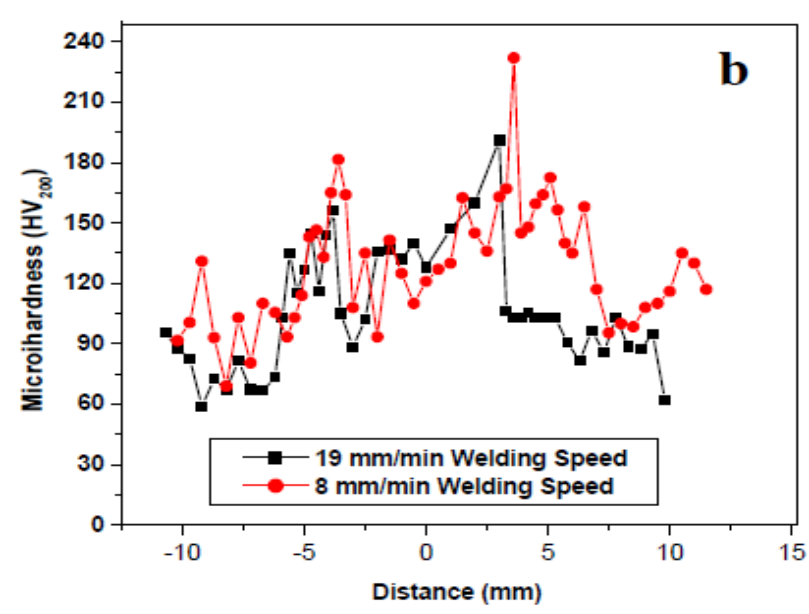

Fig 4.10: Hardness variation in weld nugget [7]

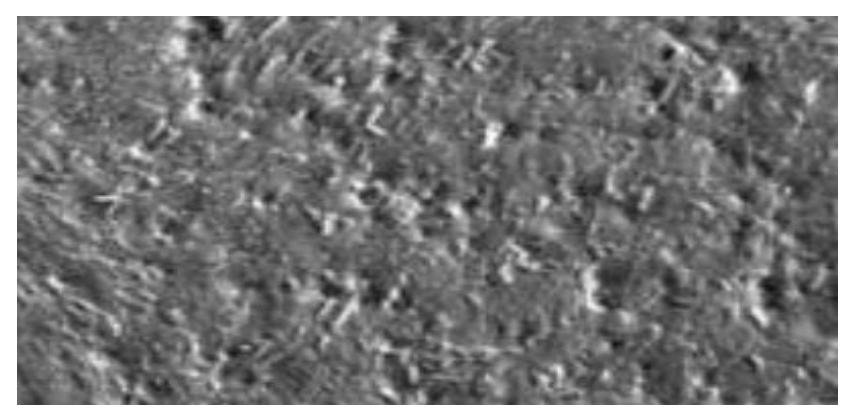

Fig 4.11: Defect free weld at $19 \mathrm{~mm} / \mathrm{min}$ welding speed [7]

4.2.3 Aluminum alloy 2219 (AA 2219)

In contrast to taper pin profile, interface region of TMAZ and NZ of the welds, generated by threaded and straight cylindrical profile showed disoriented grains even when grains appeared to be finer due to fragmentation as shown in the Optical micrographs Fig 4.12 and Fig 4.13. The Nugget Zone of the threaded pin profile was characterized by boundary misorientation of grains and finer grains compared to other pin profiles as shown by the optical micrograph in Fig 4.14. Weld produced using the threaded pin profile exhibited the maximum hardness. Welds generated by the threaded pin profile performed maximum tensile strength as shown in Fig

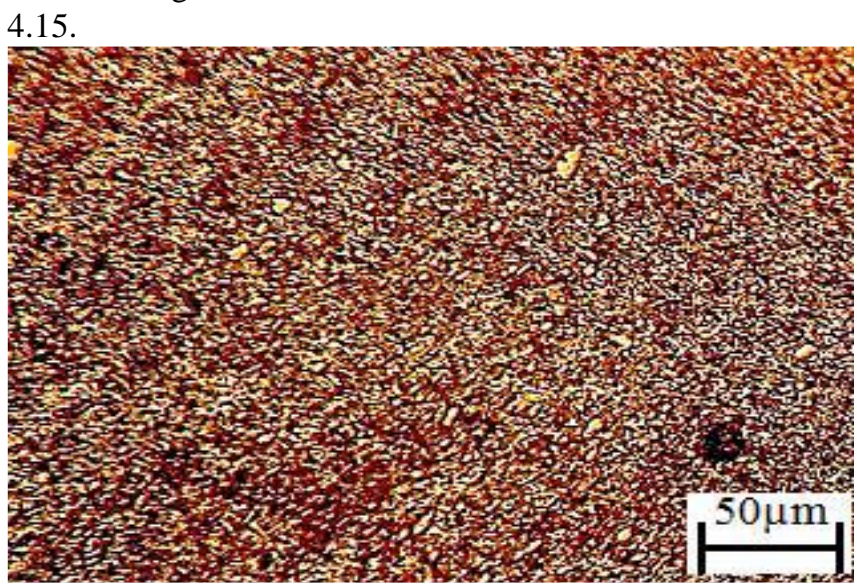

Fig 4.12: Interface zone, Threaded pin profile [8]

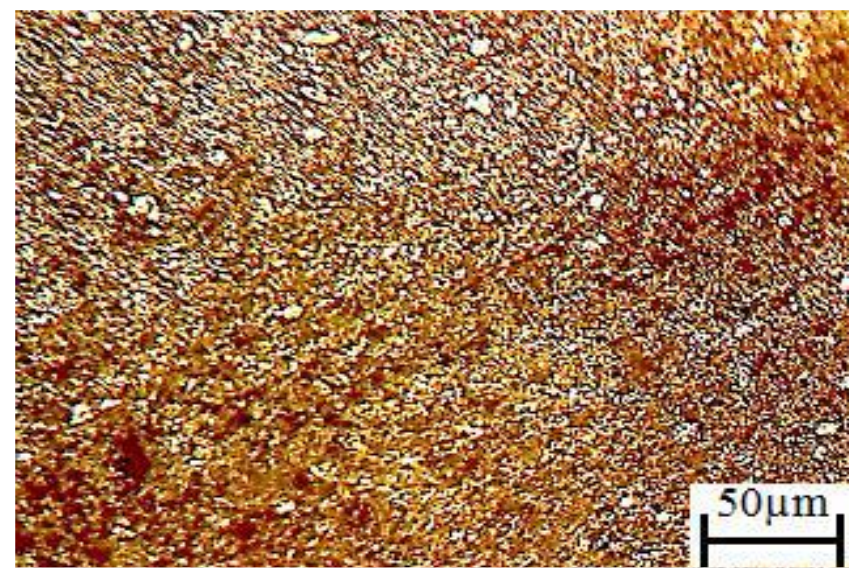

Fig 4.13: Interface zone, cylindrical pin profile [8]

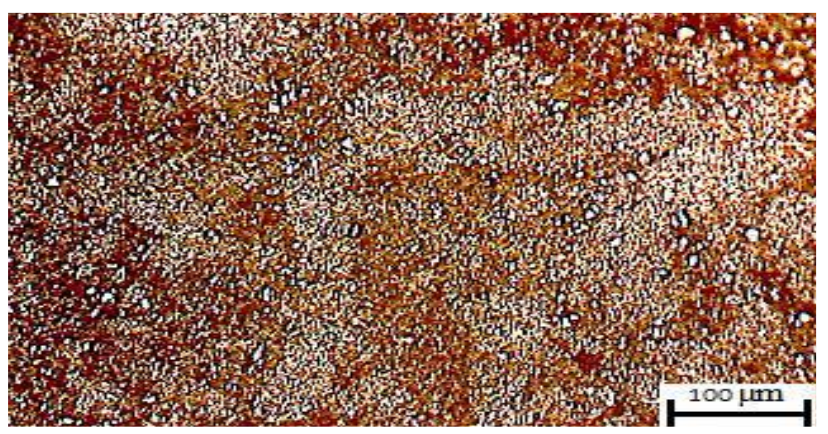

Fig 4.14: Optical micrograph of Nugget zone -Threaded pin [8]

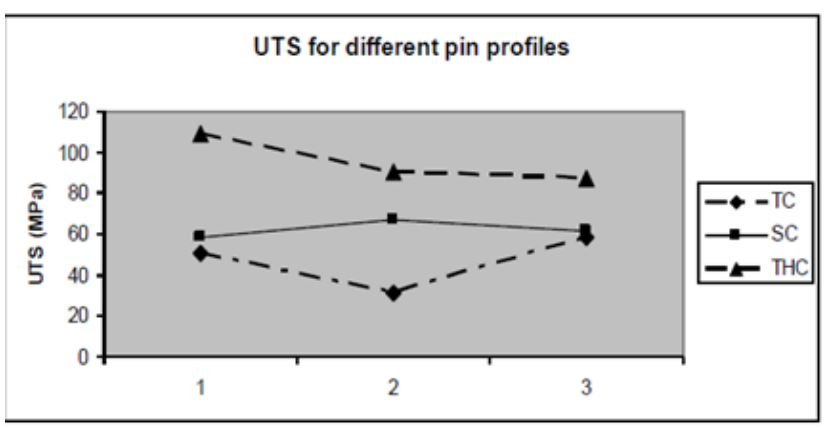

Fig 4.15: Tensile Strength for different pin profiles [8]

\subsection{Dissimilar Materials}

4.3.1 Aluminium Alloys (AA5083 - AA6061)

Grain size is significantly lesser than that the base material because of advanced temperature and extensive plastic deformation by the stirring action of the tool probe. Optimum tensile strength of $173.84 \mathrm{MPa}$ was obtained in the joint made by square pin profiled tool. As Rotation speed increases, hardness in the weldments decreases. Microstructure shows finer grains at suitable welding conditions as shown in Fig 4.16. Properties of specimens subjected to parameters are shown in Fig 4.17.

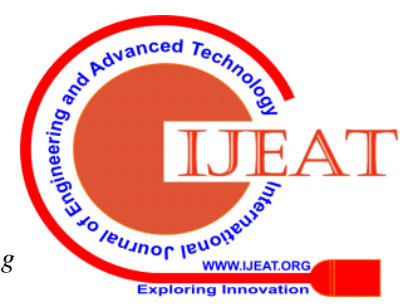




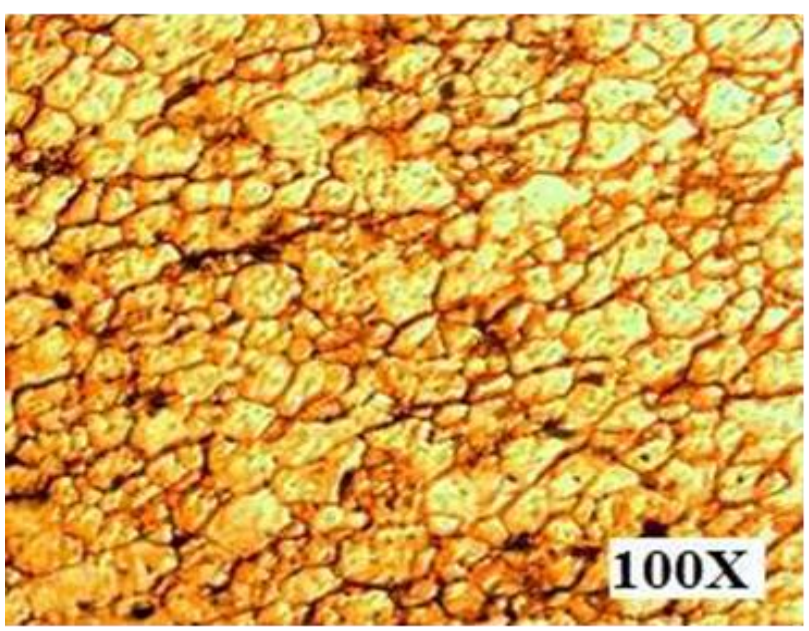

Fig 4.16: Micro structure of circular with threaded

Probe tool [9]

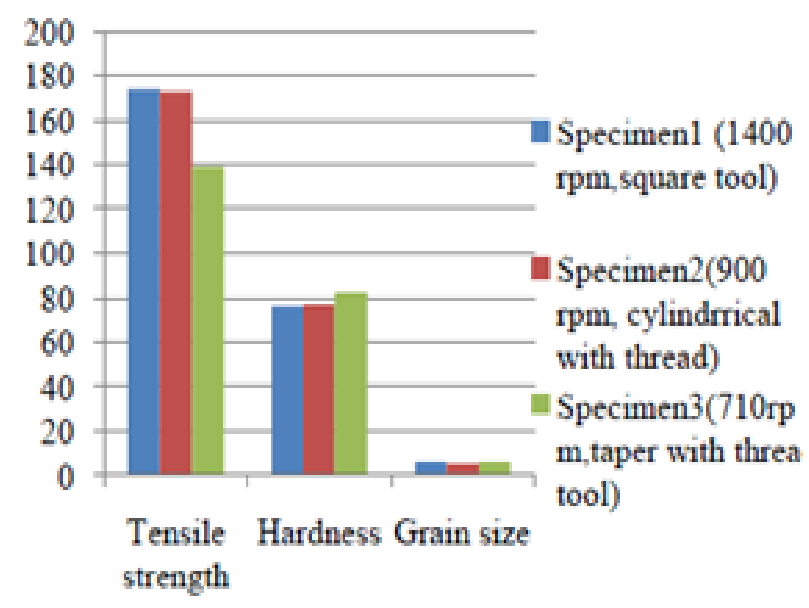

Fig 4.17: Evaluation Properties [9]

4.3.2 Aluminum -Silicon Alloy

Taper cylindrical threaded pin has given better weld and superior tensile properties of $0.182 \mathrm{kN} / \mathrm{mm}^{2}$ as shown in Fig 4.18 and 4.19 respectively. Weld made up of plain cylindrical threaded pin has given greater hardness value. Finer grain refinement of 3-4 $\mathrm{m}$ in weld nugget due to taper cylindrical threaded pin.

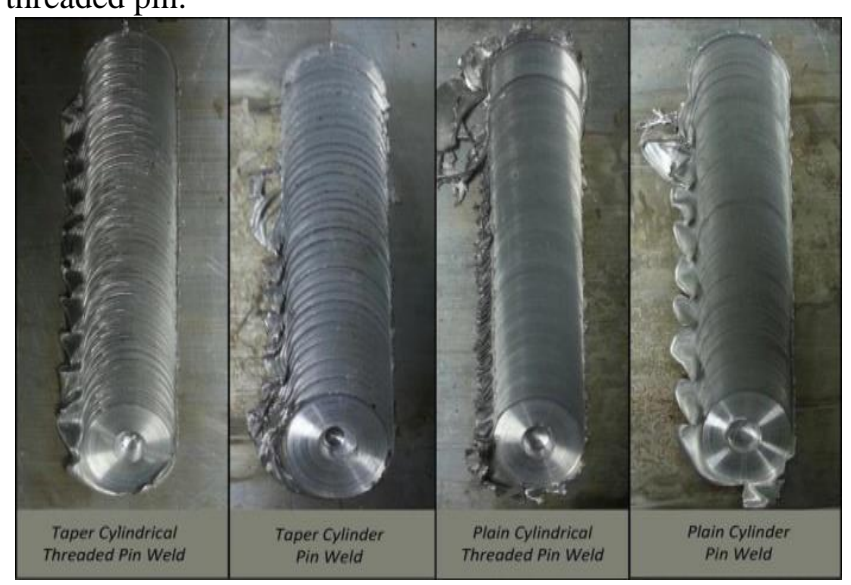

Fig 4.18: Welds Obtained using various Pin Profiles [10]

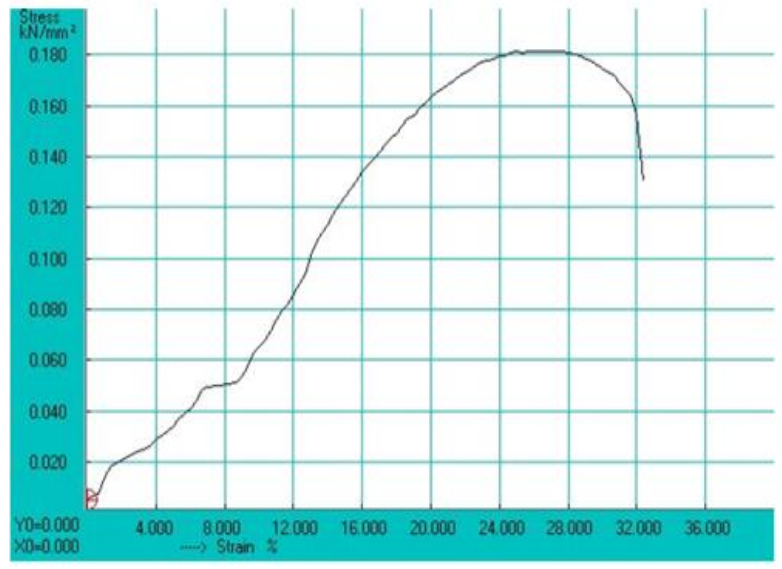

Fig 4.19: Stress vs. Strain curve for Taper Cylindrical Threaded Pin Weld [10]

4.3.3 Aluminum Alloys (AA2024-T365 and AA5083-H111)

Visible inspection revealed that defects such as tunnel and voids in the weld region as shown in Fig 4.20. It can be observed that the stirring behavior as well as the mixing of dissimilar alloys varies from one specimen to another as shown in Fig 4.21. At 1120 rpm of rotational speed as well as $1400 \mathrm{rpm}$ and $80 \mathrm{~mm} / \mathrm{min}$ achieved best strength as shown in Fig 4.22. Square pin profile gives leading strength because of pulsed action that yields good metal flow, consequently, good stirring.

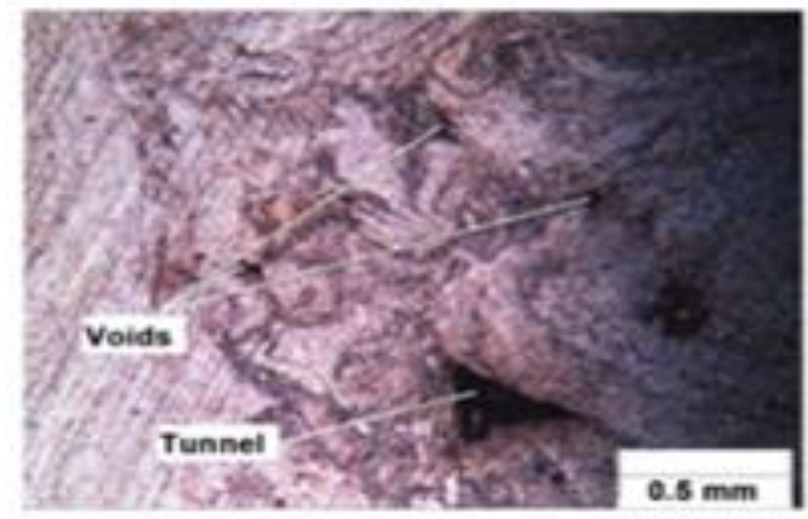

Fig 4.20: Micrographs for Some Welding Defects [11]
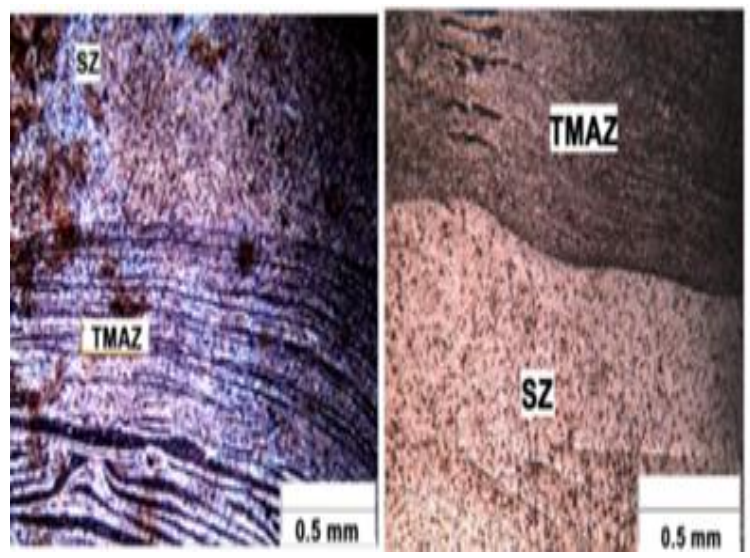

Fig 4.21: Microstructure of the SZ/TMAZ at Various Speeds [11]
Blue Eyes Intelligence Engineering \& Sciences Publication

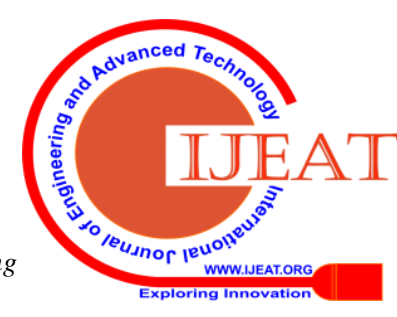


Fig 4.22: Effect of Rotational and Welding Speeds [11] 4.3.4 Aluminum Alloys (AA8011 and AA3003)

Tensile strength and Hardness Values were obtained at an optimum range of $0.141 \mathrm{kN} / \mathrm{mm} 2$ to $0.091 \mathrm{kN} / \mathrm{mm} 2$ and 62 HRC to 27 HRC respectively. Control factors have varying effects on the response variable. Fig 4.23 represents the $\mathrm{S} / \mathrm{N}$ ratio and Means for tensile strength. By optimization of results it can be concluded that the welding speed of $60 \mathrm{~mm} / \mathrm{min}$ is considering better result value in case of tensile strength. Fig 4.24 depicts S/N ratio and means for hardness.
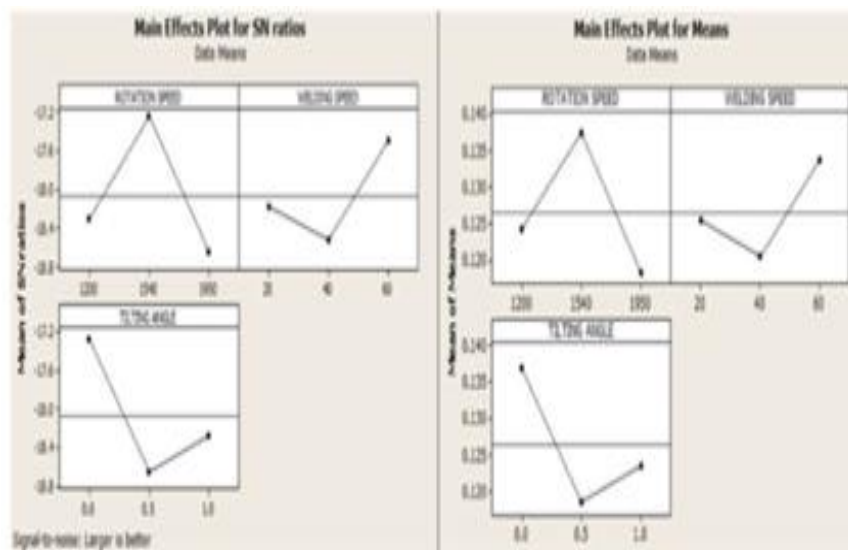

Fig 4.23: Analysis of S/N ratio and Means for Tensile Strength [12]

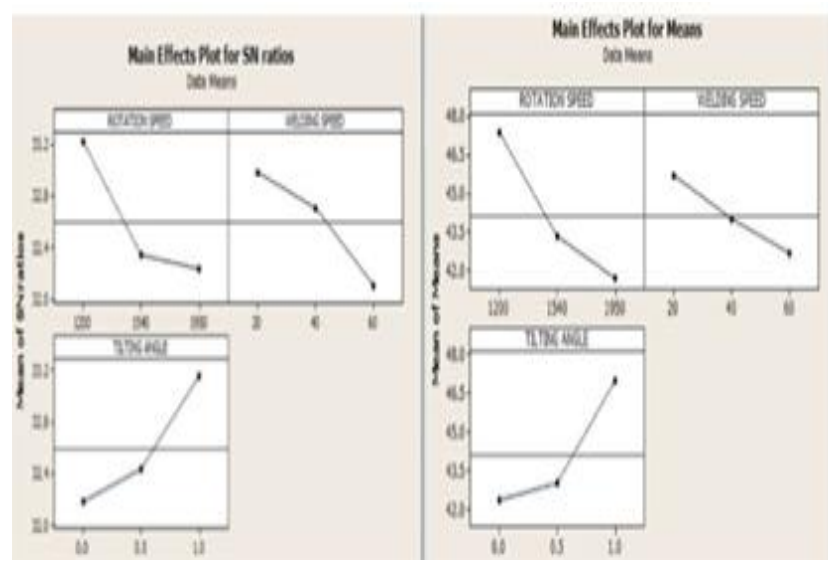

Fig 4.24: S/N ratio and Means for Hardness [12]

\section{RESULTS AND DISCUSSIONS}

5.1. Mild steel

Table I: Tensile properties obtained for different specimens [4]

\begin{tabular}{|c|c|c|}
\hline Sample ID & $\begin{array}{c}\text { Yield } \\
\text { strength } \\
\text { (MPa) }\end{array}$ & $\begin{array}{c}\text { Tensile } \\
\text { strength } \\
\text { (MPa) }\end{array}$ \\
\hline Base Metal & 250 & 492 \\
\hline Sample-1 & 300 & 490 \\
\hline Sample-2 & 305 & 492 \\
\hline Sample-3 & 330 & 420 \\
\hline Sample-4 & 335 & 425 \\
\hline
\end{tabular}

Tensile test for specimens signaled that lager magnitude of yield strength and slighter amount of uniformed elongation in comparison with parent material as shown in the Table I. This is due to the finer microstructure in $\mathrm{SZ}$ or $\mathrm{HAZ}$ region.
Joint strength was $540 \mathrm{MPa}$ at $57 \mathrm{~mm} / \mathrm{min}$ and $407 \mathrm{MPa}$ at 97 $\mathrm{mm} / \mathrm{min}$. Higher Tensile strength below $78 \mathrm{~mm} / \mathrm{min}$ traverse speed was due to hard weld nugget.

\subsection{Copper}

Table II: Tensile strength of specimens welded at different set of parameters [6]

\begin{tabular}{|c|c|c|c|}
\hline $\begin{array}{c}\text { Sl } \\
\text { no }\end{array}$ & $\begin{array}{c}\text { Rotational } \\
\text { Speed(R) }\end{array}$ & $\begin{array}{c}\text { Traverse } \\
\text { Speed } \\
(\mathrm{T})\end{array}$ & $\begin{array}{c}\text { Tensile } \\
\text { Strength } \\
(\mathrm{MPa})\end{array}$ \\
\hline 1 & 1000 & 25 & 82 \\
\hline 2 & 2500 & 10 & 104 \\
\hline 3 & 5500 & 40 & 89 \\
\hline 4 & 2500 & 40 & 77 \\
\hline 5 & 4000 & 10 & 110 \\
\hline 6 & 1000 & 55 & 62 \\
\hline 7 & 5500 & 25 & 104 \\
\hline 8 & 1000 & 40 & 65 \\
\hline 9 & 2500 & 25 & 89 \\
\hline 10 & 5500 & 55 & 75 \\
\hline 11 & 1000 & 10 & 92 \\
\hline 12 & 2500 & 55 & 67 \\
\hline 13 & 4000 & 40 & 82 \\
\hline 14 & 5500 & 10 & 112 \\
\hline 15 & 4000 & 55 & 74 \\
\hline 16 & 4000 & 25 & 103 \\
\hline
\end{tabular}

Experiments are conducted with combination of selected parameters by full factorial design matrix as shown in Table II. Tensile strength of specimens is in the range of 62 to 112 MPa.

\subsection{Copper}

Ultimate tensile strength of $256.9 \mathrm{MPa}$ at $19 \mathrm{~mm} / \mathrm{min}$ was obtained. Optimum hardness was achieved in retreating side of weld nugget for welding speeds.

\subsection{Aluminium Alloys (AA5083 and AA6061)}

Table III: Tensile properties [9]

\begin{tabular}{|c|c|c|c|}
\hline Specimen & $\begin{array}{c}\text { Ultimate } \\
\text { tensile } \\
\text { strength } \\
\text { (Mpa) }\end{array}$ & $\begin{array}{c}\text { \% of } \\
\text { Elongation }\end{array}$ & $\begin{array}{c}\text { Yield } \\
\text { strength } \\
\text { (Mpa) }\end{array}$ \\
\hline 1 & 173.84 & 5.3 & 127.12 \\
\hline 2 & 172.29 & 7.32 & 101.86 \\
\hline 3 & 138.94 & 3.58 & 89.95 \\
\hline
\end{tabular}

Higher tensile strength of $173.84 \mathrm{MPa}$ was obtained to the joint made up of square pin profiled. A lower tensile strength of 138.94MPa was attained in the joint made by taper with threaded pin profile as shown in Table III.

Table IV: Hardness and Impact (Charpy), Grain size Properties [9]

\begin{tabular}{|c|c|c|c|}
\hline Specimen & $\begin{array}{c}\text { Hardness } \\
(\mathrm{HV})\end{array}$ & Impact $(\mathrm{J})$ & $\begin{array}{c}\text { Grain } \\
\text { Size }(\mu \mathrm{m})\end{array}$ \\
\hline 1 & 76.3 & 30 & 6 \\
\hline 2 & 76.87 & 30 & 5 \\
\hline 3 & 82.13 & 14 & 6 \\
\hline
\end{tabular}

Value of hardness was $82.13 \mathrm{HV}$ which was obtained by taper with threaded tool because of low tool rotation speed (710 $\mathrm{rpm}$ ) and welding speed $31.5 \mathrm{~mm} / \mathrm{min}$.

5.6 Aluminum -Silicon Alloy

\subsection{High strength low alloy steel}


Table V: Tensile test results [10]

\begin{tabular}{|c|c|c|c|c|}
\hline Properties & $\begin{array}{c}\text { Ultimate } \\
\text { Tensile } \\
\text { Strength } \\
\left(\mathrm{kN} / \mathrm{mm}^{2}\right)\end{array}$ & $\begin{array}{c}\text { \% of } \\
\text { Elongation }\end{array}$ & $\begin{array}{c}\text { Reduction } \\
\text { in Area } \\
(\%)\end{array}$ & $\begin{array}{c}\text { Joint } \\
\text { Efficiency } \\
(\%)\end{array}$ \\
\hline $\begin{array}{c}\text { Taper } \\
\text { cylinder } \\
\text { threaded }\end{array}$ & 0.182 & 14.867 & 35.964 & 58.71 \\
\hline $\begin{array}{c}\text { Plain } \\
\text { cylinder } \\
\text { threaded }\end{array}$ & 0.183 & 3.5 & 9.222 & 59.03 \\
\hline $\begin{array}{c}\text { Taper } \\
\text { threaded }\end{array}$ & 0.167 & 6.667 & 32.645 & 53.87 \\
\hline $\begin{array}{c}\text { Plain } \\
\text { threaded }\end{array}$ & 0.134 & 1.033 & 6.761 & 43.23 \\
\hline
\end{tabular}
unthreaded pins. In case of the two threaded pin profiles, the taper cylindrical threaded pin profile has higher elongation properties than the plain cylindrical threaded pin profile as pin profile yielded superiors tensile characteristics among the four pin profiles.

Table VI: Micro-hardness obtained through Micro-Vickers hardness testing [10]

\begin{tabular}{|c|c|c|c|c|}
\hline $\begin{array}{c}\text { Pin } \\
\text { Profile }\end{array}$ & $\begin{array}{c}\text { Taper } \\
\text { cylindrical } \\
\text { thread }\end{array}$ & $\begin{array}{c}\text { plain } \\
\text { cylindrical } \\
\text { thread }\end{array}$ & $\begin{array}{c}\text { Taper } \\
\text { thread }\end{array}$ & $\begin{array}{c}\text { plain } \\
\text { thread }\end{array}$ \\
\hline $\begin{array}{c}\text { Hardness } \\
\text { No } \\
\text { (VHN) }\end{array}$ & 68.71 & 75.03 & 68.43 & 50.87 \\
\hline
\end{tabular}

Value of the weld made of plain cylindrical threaded pin profile was the highest among the welds made as show in Table VI.

5.7 Aluminum Alloys (AA2024-T365 and AA5083-H111)

Square pin profile gives higher strength joints compared to prism and stepped profiles because of pulses per revolution.

5.8 Aluminum Alloys (AA8011 and AA3003)

Table VII: Critical parameters [12]

\begin{tabular}{|c|c|}
\hline Factors & $\begin{array}{c}\text { Most effected } \\
\text { parameter }\end{array}$ \\
\hline Tensile strength & Rotation speed \\
\hline \% Elongation & $\begin{array}{c}\text { Rotation speed and tilt } \\
\text { angle }\end{array}$ \\
\hline Hardness & Rotation speed \\
\hline
\end{tabular}

Influential parameters are shown in Table VII. Higher the rotational speed maximum will be the joint strength and for \% Elongation, the combination of rotation speed, welding speed and tilting angle is $1540 \mathrm{rpm}, 20 \mathrm{~mm} / \mathrm{min}$ and $0 \mathrm{deg}$. parameter value of $1200 \mathrm{rpm}$ (rotation speed), $20 \mathrm{~mm} / \mathrm{min}$ (welding speed) and 1 deg (tilting angle) are considered as suitable results better hardness.

\section{WELDING PARAMETERS ON FRICTION STIR WELDING}

The process of effective friction stir welding largely depends upon its parameters which will be used for determining
Threaded pins have better tensile properties than the shown in Table IV. Welds made of taper cylindrical threaded

mechanical and various properties. Hence the welding parameters play a vital role in selecting the materials for experimental investigations. Literature survey indicates various critical parameters that influence the process. Following tables suggest the various parameters of friction stir welding used in ferrous, non -ferrous and dissimilar joining of several combinations of materials.

Table VIII: Parameters used in ferrous materials

\begin{tabular}{|c|c|c|c|c|c|c|c|c|c|c|c|}
\hline \multirow{5}{*}{$\begin{array}{l}\text { Permous } \\
\text { Materials }\end{array}$} & \multirow{3}{*}{$\begin{array}{l}\text { Sl } \\
\text { No }\end{array}$} & \multicolumn{10}{|c|}{ Parameters Assessed } \\
\hline & & \multirow[b]{2}{*}{$\begin{array}{l}\text { Rotational } \\
\text { Speed } \\
\text { (Rpom) }\end{array}$} & \multirow{2}{*}{$\begin{array}{l}\text { Weldiug } \\
\text { Speed } \\
\text { (MmMin) }\end{array}$} & \multirow{2}{*}{$\begin{array}{c}\text { Tool } \\
\text { Material }\end{array}$} & \multirow{2}{*}{$\begin{array}{c}\text { Tool } \\
\text { Force } \\
\mathrm{kN}\end{array}$} & \multirow{2}{*}{$\begin{array}{c}\text { Tool } \\
\text { Till } \\
\text { Angle } \\
0\end{array}$} & \multicolumn{5}{|c|}{ Tool Piu Profile } \\
\hline & & & & & & & Square & Cyimdrical & Stepped & Tapered & $\begin{array}{c}\text { Equilateral } \\
\text { Triangle }\end{array}$ \\
\hline & 01 & $\checkmark$ & $\checkmark$ & $\begin{array}{c}\text { Tungsten } \\
\text { Alloy }\end{array}$ & . & $\checkmark$ & · & $\cdot$ & $\cdot$ & $\checkmark$ & . \\
\hline & 02 & $\checkmark$ & $\checkmark$ & $\begin{array}{l}\text { Tungsten } \\
\text { thentum } \\
\text { Alloy }\end{array}$ & $\checkmark$ & . & . & $\checkmark$ & . & $\checkmark$ & . \\
\hline
\end{tabular}

Table IX: Parameters used in Non -ferrous materials

\begin{tabular}{|c|c|c|c|c|c|c|c|c|c|c|c|c|}
\hline \multirow{6}{*}{$\begin{array}{l}\text { Non } \\
\text { Ferrouls } \\
\text { Matenials }\end{array}$} & & \multicolumn{11}{|c|}{ Patainetelds Assessed } \\
\hline & \multirow[b]{2}{*}{$\begin{array}{l}81 \\
\mathrm{NO}\end{array}$} & \multirow{2}{*}{ 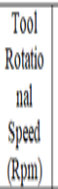 } & \multirow{2}{*}{$\begin{array}{l}\text { Welding } \\
\text { Sped } \\
\text { MmMi } \\
\text { i) }\end{array}$} & \multirow[b]{2}{*}{$\begin{array}{c}\text { Tool } \\
\text { Matcinal }\end{array}$} & \multirow[b]{2}{*}{$\begin{array}{l}\text { Tool } \\
\text { Potee } \\
\mathbb{B N}\end{array}$} & \multirow[b]{2}{*}{$\begin{array}{c}\text { Tool } \\
\text { Tilit } \\
\text { Angle } \\
i\end{array}$} & \multicolumn{6}{|c|}{ Tool Pitil Profle } \\
\hline & & & & & & & \$quare & Cylindrical & Stepped & Tapered & Tiriangle & Threaded \\
\hline & 01 & l & $\sqrt{ }$ & $\begin{array}{l}\text { AISI } \\
4140\end{array}$ & . & $\cdot$ & $\cdot$ & $\sqrt{ }$ & . & . & . & . \\
\hline & 02 & l & $\sqrt{ }$ & 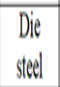 & . & $\checkmark$ & . & . & . & . & . & $\sqrt{ }$ \\
\hline & 03 & l & $\sqrt{ }$ & $\begin{array}{l}1.13 \\
1001 \\
5+1\end{array}$ & $\sqrt{ }$ & . & . & $\sqrt{ }$ & $\cdot$ & $\checkmark$ & . & $\sqrt{ }$ \\
\hline
\end{tabular}

Table X: Parameters used in dissimilar materials

\begin{tabular}{|c|c|c|c|c|c|c|c|c|c|c|c|c|}
\hline \multirow{7}{*}{$\begin{array}{l}\text { Dissinily } \\
\text { Naterials }\end{array}$} & \multirow{3}{*}{$\begin{array}{l}\$ ! \\
\$ 10\end{array}$} & \multicolumn{11}{|c|}{ Parameter Assesed } \\
\hline & & \multirow{2}{*}{$\begin{array}{c}\text { Tool } \\
\text { Rotational } \\
\text { Spoed } \\
\text { (Rpom) } \\
\end{array}$} & \multirow{2}{*}{$\begin{array}{c}\text { Welding } \\
\text { Spend } \\
(\mathrm{Mm} M \mathrm{Ni} \\
\text { 1) }\end{array}$} & \multirow{2}{*}{$\begin{array}{c}\text { Iool } \\
\text { Nateral } \\
\end{array}$} & \multirow{2}{*}{$\begin{array}{l}\text { Iool } \\
\text { foroe } \\
\text { WN }\end{array}$} & \multirow{2}{*}{\begin{tabular}{|c|} 
Tool \\
Tilit \\
Angle \\
0 \\
\end{tabular}} & \multicolumn{6}{|c|}{ Tool Pia Profile } \\
\hline & & & & & & & Square & Cylindial & Stepped & Tapend & Trimale & Thraded \\
\hline & $0 !$ & $\checkmark$ & $\checkmark$ & $\begin{array}{l}\text { Hill } \\
\text { stell }\end{array}$ & . & $\checkmark$ & . & . & $\cdot$ & $\cdot$ & , & $\checkmark$ \\
\hline & $0 ?$ & $\checkmark$ & $\checkmark$ & HSS & $\cdot$ & . & . & $\checkmark$ & . & $\checkmark$ & & $\checkmark$ \\
\hline & 03 & $\checkmark$ & $\checkmark$ & $\begin{array}{l}\text { Hil3 } \\
\text { Stewl }\end{array}$ & . & . & $\checkmark$ & . & $\checkmark$ & . & . & . \\
\hline & 04 & $\checkmark$ & $\checkmark$ & $\begin{array}{c}\text { Hil3 dife } \\
\text { statel }\end{array}$ & & . & · & $\checkmark$ & . & · & · & $\cdot$ \\
\hline
\end{tabular}

\section{CONCLUSION AND SCOPE OF FUTURE WORK}

Friction Stir Welding as studied in the conceptual definitions offered wide range of process benefits that meets specific application area. This process tendered various flexible parameters for the materials chosen for welding purpose.

Published By:

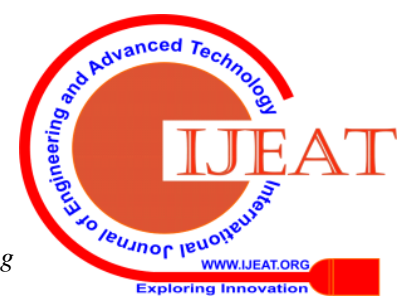


Friction Stir Welding (FSW) successfully overwhelm the difficulties occurred in conventional welding techniques and several literatures justifies this statement. Hence this can be considered as a widely recognized procedural activity and suitable for the research aspects to unearth the undefined materials and their beneficial characteristics. In this regard the research based on FSW should intensify its finding for newer combination of materials.

1. Many researchers have been already carried out to demonstrate the extensive work on joining similar and dissimilar materials, but very few investigations have been elaborated on polymeric materials like metal to polymer combinations.

2. Practicality of joining processes involving metal and plastic components by welding source can lead to achieve specifically optimized characteristics.

3. Hybrid metal - polymer coupling extends adopting properties and productivity in terms of required design and manufacturing variability alongside with overall weight reduction in components.

4. Maximize effectively the welding parameters to ensure a proper balance in mechanical performance.

Finally, FSW already proven to be an optimum welding technique by successfully joining all kinds of materials (ferrous and non ferrous) available yielding satisfactory results that covers suitable application aspects also. There are some areas interms of material selection where its operational functions still need to be achieved. In this regard the, FSW process should be implemented for polymeric material combinations to unleash newer characteristics.

\section{REFERENCES}

1. Anjal R. Patel, Chirag G. Dalwadi , Harikrishna G. Rana "A Review: Dissimilar Material Joining of Metal to Polymer using Friction Stir Welding (FSW)" International Journal of Science Technology \& Engineering, Volume 2 , Issue 10, April 2016.

2. C.M. Dinesh, B. Gajendra Kumar, S. Ganapathi, M. Gandhi, M. Janarthanan "Prediction of Al-Mg Metals using Friction Stir Welding" International Journal of Engineering Science and Computing, Volume 7, Issue No.4 , April 20317.

3. D.Aravindkumar, A.Balamurugan "A Review On Friction Stir Welding Of Dissimilar Materials Between Aluminium Alloys To Copper" International Journal of Latest Research in Engineering and Technology (IJLRET), Volume 2 Issue 2, February 2016, PP 09-15.

4. Saman Karami, Hamidreza Jafarian, Ali Reza Eivani, Shahram Kheirandish “ Engineering Properties By Controlling Welding Parameters And Microstructure In A Mildsteel Processed By Friction Stir Welding" Materials Science And Engineering A ,670, 2016, PP 68-74.

5. R. Ramesha,, I. Dinaharanb, Ravi Kumarc, E.T. Akinlabib "Microstructure and mechanical characterization of friction stir welded high strength low alloy steel” Materials Science \& Engineering A 687 (2017), PP 39-46.

6. Pankaj kumar, Satpal Singh, Gurmeet Singh, Ankit Dua "Effect Of Process Parameters On Tensile Strength Of Friction Stir Welded Joint Of Pure Copper" IOSR Journal of Mechanical and Civil Engineering (IOSR-JMCE) IOSR Journal of Mechanical and Civil Engineering (IOSR-JMCE).

7. Dr. K. Lenin and S. Dharmalingam "Effect of Friction Stir Welding on Microstructural and Mechanical Properties of Copper Alloy" Advances in Natural and Applied Sciences. 11(4) April 2017, Pages: 484-493

8. Sreenivas $P$ and Sreejith P S "Effect of Process Parameters on Microstructural and Mechanical Properties of Friction Stir Welded 2219 Aluminium Alloys" International Journal of Theoretical and Applied Mechanics, ISSN 0973-6085 Volume 12, Number 1 (2017) ,PP 135-146.

9. Buddi Manohar, Satishkumar. P, Aruri Devaraju "Effect Of Microstructure And Mechanical Properties Of Friction Stir Welded Dissimilar Aa5083-Aa6061 Aluminium Alloy Joints", IJRET: International Journal of Research in Engineering and Technology,
Volume: 05 Issue: 11, Nov-2016, eISSN: 2319-1163 , pISSN: 2321-7308S

10. Thirumavalavan, R. Sabarish, U. Ganesan "Experimental Investigation On Friction Stir Welded Aluminium -Scilicon Alloy", International Journal of Mechanical Engineering and Technology (IJMET), Volume 8, Issue 8, August 2017, PP. 1629-1641, Article ID: IJMET_08_08_177.

11. Hassan Abd El-Hafez, Abla El-Megharbel "Friction Stir Welding of Dissimilar Aluminum Alloys", World Journal of Engineering and Technology", 2018, 6, PP 408-419.

12. Yudhvir, Gurpinder Singh, Ashwani Kumar "Optimization Of Friction Stir Welding Parameters For Dissimilar Aluminum Alloy” International Journal Of Management, Technology and Engineering, Volume IX, Issue I, JANUARY/2019, ISSN NO: 2249-7455.

\section{AUTHORS PROFILE}

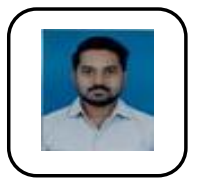

Mahendra K C Completed Master's of Technology in Production Engineering and Systems Technology, in the Year 2014 from Visvesvaraya Technological University, Belagavi.Working as an Assistant Professor in the Department of Mechanical Engineering. R.Y.M.E.C Ballari. Having 5 years of teaching experience. Pursuing doctoral degree in Visvesvaraya Technological University -Belagavi on Friction Stir Welding. Publications in 04 international Journals. Member of MISTE.

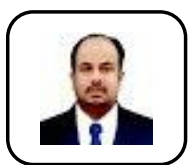

Sreenivasa C. G. Associate Professor, Department of Mechanical Engineering UBDTCE, Davangere. Having a Teaching Experience of 16 Years. Deputed to VTU NASD as Director (I/C). Research articles are published in various national/International journals and conferences. Organized and coordinated various short terms training programme in institute and department level. Invited as special/guest to deliver on various aspects of mechanical fields. His area of interest includes agile manufacturing , lean manufacturing and industrial engineering. Life member in ISTE and member in international association of engineers. Presently he is guiding for 3 research scholars for doctoral degree.

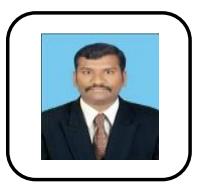

Veerabhadrappa Algur received his Ph.D in Mechanical Engineering from the Visvesvaraya Technological University -Belagavi in 2018. He is currently an Associate professor in the Department of Mechanical Engineering at R Y M Engineering College, Ballari. Held complete responsibility to develop full pledged Tribology lab at Mechanical Engineering R\&D centre. He has published more than 50 research articles in leading journals and conference proceedings. His research interest includes Tribology, Design of experiments, and composites. He is a member of Editorial Reviewer Board for International Journal of Advances in Scientific Research and Engineering, American Journal of Mechanical and Industrial Engineering and Tribology of Industry.

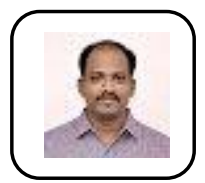

Virupaksha Gouda H obtained master's degree from Visvesvaraya Technological University -Belagavi and pursuing doctoral degree in Visvesvaraya Technological University -Belagavi on Bio- composite materials. Having 05 years of teaching experience and 08 years of industry.Presently working as Assistant Professor in Department of Mechanical Engineering at R Y M Engineering College, Ballari. Having Publications in National, international and conferences proceedings. Member of MISTE. 